\title{
A rare ectopic ACTH secreting atypical pulmonary carcinoid- case report
}

\author{
Jain N. ${ }^{\mathbf{*}}$, Gidwani $\mathbf{N}^{2}$ \\ DOI: https://doi.org/10.17511/jopm.2020.i01.17 \\ 1* Niharika Jain, Final Year Pathology Resident, Department of Pathology, Mahatma Gandhi Medical College and Hospital, Jaipur, Rajasthan, \\ India. \\ 2 Nikita Gidwani, Final Year Pathology Resident, Department of Pathology, Mahatma Gandhi Medical College and Hospital, Jaipur, Rajasthan, \\ India.
}

Pulmonary carcinoids are rare pulmonary neoplasms which account for $1-2 \%$ of all lung neoplasms. Pulmonary carcinoid tumors are a rare cause of ectopic ACTH secretion. The incidence of Cushing's syndrome in pulmonary carcinoid tumor is approximately $1 \%$. A case of 25 -year-old young male with typical cushingoid appearance presented with headache on and off and episodes of hypertension since 1year.Thoracic CT revealed a nodular region in left lower lobe. The patient underwent left lower lobectomy and histopathology revealed an atypical carcinoid tumor. On immunohistochemistry, tumor cells were positive for CK PAN9, CD117, S100, TTF-1, synaptophysin, chromogranin and negative for $\mathrm{P} 40, \mathrm{CK} 7, \mathrm{Her}-2$ and $\mathrm{CD} 99$. This case is presented for its rarity.

Keywords: Pulmonary, Ectopic Cushing's, Carcinoid tumor

Corresponding Author

Niharika Jain, Final Year Pathology Resident, Department of Pathology, Mahatma Gandhi Medical College and Hospital, Jaipur, Rajasthan, India. Email: niharika.oct10@yahoo.in
How to Cite this Article

Jain N, Gidwani N. A rare ectopic ACTH secreting atypical pulmonary carcinoid- case report. Trop J Pathol Microbiol. 2020;6(1):103-107.

Available From

https://pathology.medresearch.in/index.php/jopm/ar ticle/view/407
To Browse

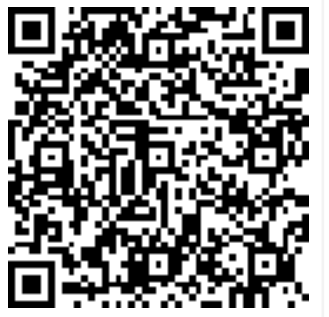

\section{Introduction}

Carcinoid tumors are the neuroendocrine tumors arising from enterochromaffin cells (type of enteroendocrine or neuroendocrine cells occurring in epithelia lining of digestive tract and respiratory tract that release serotonin). The gastrointestinal tract is the most common site for carcinoid tumors. Of all carcinoids, bronchopulmonary carcinoids represent only $10 \%$ cases.

Pulmonary carcinoids are rare pulmonary neoplasms which account for $1-2 \%$ of all lung

Manuscript Received 10-01-2020

Conflict of Interest No

Review Round 1
20-01-2020
Funding
Nil

Review Round 2
$25-01-2020$
Ethical Approval
Yes

Neoplasms. Bronchial carcinoids represent small portion of all pulmonary tumors and about $1-5 \%$ of them are associated with ectopic ACTH secretion, which represents 1$10 \%$ of Cushing syndrome cases [1-3]. They are a rare cause of ectopic ACTH secretion.

Cushing syndrome is the result of chronic exposure to increased concentration of cortisol hormone, exogenous or endogenous. The endogenous Cushing syndrome comprises three distinct pathogenic disorders: pituitary, adrenal and ectopic [4]. Ectopic Cushing syndrome (ECS) results from autonomous

(c) 2020 by Niharika Jain, Nikita Gidwani and Published by Siddharth Health Research and Social Welfare Society. This is an Open Access article licensed under a Creative Commons Attribution 4.0 International License https://creativecommons.org/licenses/by/4.0/ unported [CC BY 4.0].

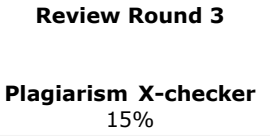

Review Round 3 Plagiarism X-checker $15 \%$

Accepted 29-01-2020 Note 
ACTH production from extra pituitary malignancies with elevated plasma levels of ACTH accounting for $15 \%$ of cases of Cushing syndrome [5]. It is generally associated with central obesity, metabolic syndrome and hypertension [6]. Neuropsychological disturbances are also frequently observed including depression, emotional irritability, sleep disturbances and cognitive deficits that can be the first manifestation perceived by family members of patients affected by Cushing's syndrome.

Typical carcinoids are more common and atypical carcinoids are the rarer ones among all pulmonary carcinoids. Treatment is based on decreasing the cortisol levels in blood. Surgery is considered as the mainstay of treatment for ectopic ACTH secreting tumors.

\section{Case Report}

A 25-year-old young male presented with headache on and off and episodes of hypertension since 1 year.

On physical examination, the patient presented with Cushingoid features (moon facies, extensive purple striae on abdomen and arms, marked central obesity and peripheral edema.

Blood pressure was high (158/90 mm Hg), cardiac and pulmonary auscultations were normal and there were no abdominal palpable masses.

Routine laboratory results showed-

- Hypercholesterolemia (total cholesterol-270 $\mathrm{mg} / \mathrm{dL}$, HDL cholesterol, $82 \mathrm{mg} / \mathrm{dL}$, LDL cholesterol $171 \mathrm{mg} / \mathrm{dL}$ and triglycerides 152 $\mathrm{mg} / \mathrm{dL}$ )

- Elevated plasma glucose $132 \mathrm{mg} / \mathrm{dL}$ with HbA1c $6.03 \%$

- $\mathrm{Hb}-13.5 \mathrm{~g} / \mathrm{dL}$

- Hypokalemia $(\mathrm{K}+=2.6 \mathrm{mmol} / \mathrm{L})$ with no other electrolyte disturbances.

- Renal function tests and liver function tests were normal.

As clinical suspicion of endogenous hypercortisolism was high, screening for cortisol levels was done.

Table 1: ACTH levels.

\begin{tabular}{|l|l|l|l|}
\hline \multicolumn{2}{|c|}{ Morning } & \multicolumn{2}{c|}{ Evening } \\
\hline $11.26 \mathrm{am}$ & $255 \mathrm{pg} / \mathrm{ml}$ & $3.42 \mathrm{pm}$ & $237 \mathrm{pg} / \mathrm{ml}$ \\
\hline $11.30 \mathrm{am}$ & $268 \mathrm{pg} / \mathrm{ml}$ & $3.44 \mathrm{pm}$ & $234 \mathrm{pg} / \mathrm{ml}$ \\
\hline $11.32 \mathrm{am}$ & $272 \mathrm{pg} / \mathrm{ml}$ & $3.47 \mathrm{pm}$ & $216 \mathrm{pg} / \mathrm{ml}$ \\
\hline $11.35 \mathrm{am}$ & $292 \mathrm{pg} / \mathrm{ml}$ & & \\
\hline
\end{tabular}

Tests revealed elevated cortisol levels $(45.8 \mu \mathrm{g} / \mathrm{dL})$ and plasma ACTH levels.

To identify a potential pituitary lesion, a pituitary MRI was performed, there was no identifiable tumor. Bilateral Inferior Petrosal Sinus Sampling (IPSS) revealed peripheral source of $\mathrm{ACTH}$.

Plain chest X-ray showed no abnormalities. Bronchoscopy and cytological examination of bronchoalveolar lavage were negative for malignancy.

Chest CT scan revealed one nodular lesion in the left lower lobe of lung measuring $1.1 \times 0.8 \mathrm{~cm}$. A whole body

Ga-68 DOTANOC PET CT was planned to characterize the lesion as well as to localize metastatic lymph node which revealed centimetric nodular lesion $(1.1 \times 0.8 \mathrm{~cm})$ with no significant tracer uptake was seen in left lung lower lobe and a possibility of atypical carcinoid/small cell carcinoma was made.

The patient underwent lower lobe lobectomy of left lung. The resected specimen was sent for histopathological examination.

\section{Pathological findings}

Gross- Lower lobe of left lung was received measuring $10 \times 7 \times 4 \mathrm{~cm}$. Bronchus was identified on careful examination, just adjacent to it a growth measuring $1 \times 0.5 \mathrm{~cm}$ was present (Figure 1 ).

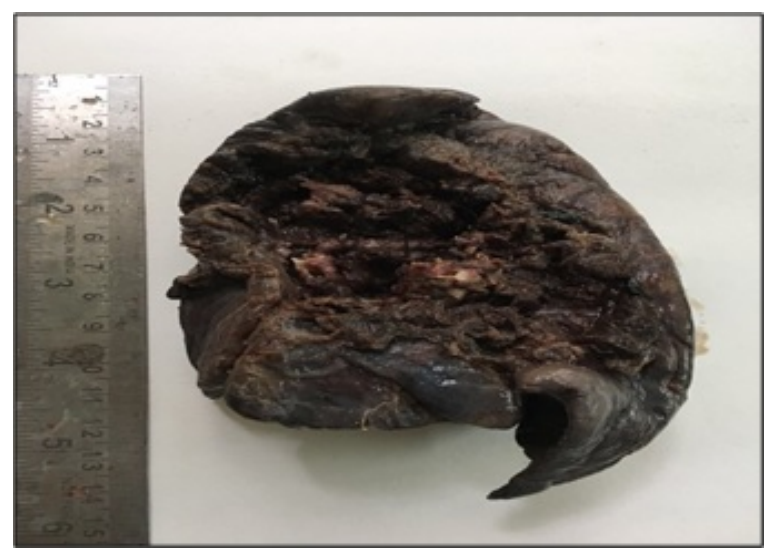

Fig-1: Gross image of lower lobe of left lung.

Microscopy- Sections given from nodular area comprised of nests of uniform population of cells. Cells had scanty to moderate granular cytoplasm. Nuclei were round to oval and central having granular chromatin and inconspicuous nucleoli. Occasional mitotic activity was seen. Surrounding 
Lung parenchyma showed occasional tiny satellite nodules. Rest of the lung parenchyma showed congestion of blood vessels and small number of alveolar macrophages. The resected margin of specimen was free from tumor invasion.

Overall picture was suggestive of atypical bronchial carcinoid tumor.

Immunohistochemistry was advised for proper evaluation.

Markers positive in tumor cells were CK PAN9 (dot like), CD117, ACTH, S100, Synaptophysin, TTF-1and Chromogranin; negative markers were P40, CK7, Her-2, CD99.

Immunomarkers favored neuroendocrinal tumor with features of atypical carcinoid.

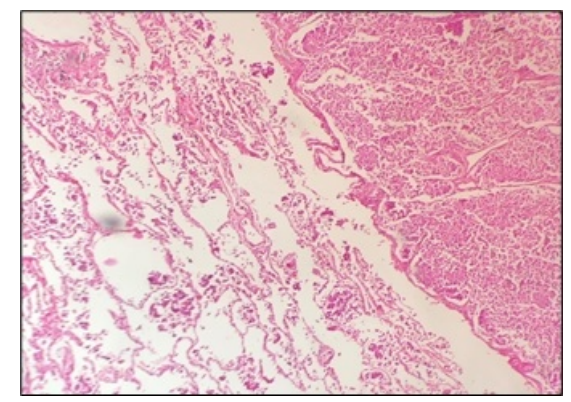

Fig-2: Section representing area of a normal lung and the nodular area.
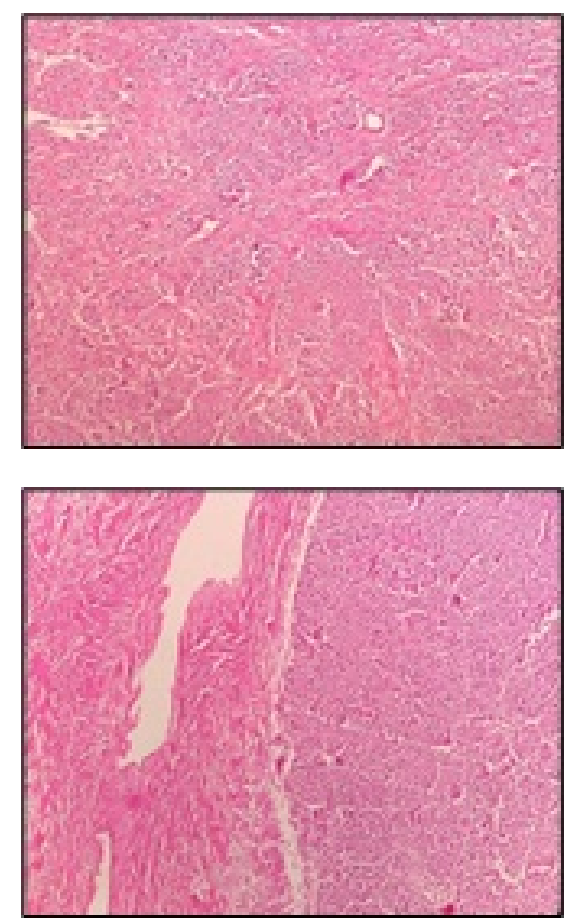

Fig-3: Image representing section from the nodular area.

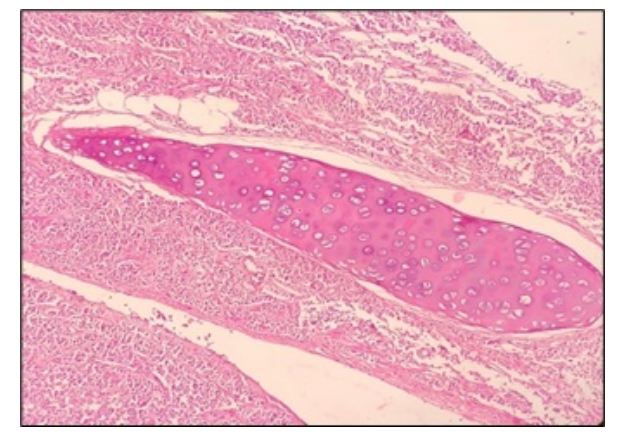

Fig-4: Image representing section of the bronchial cartilage.

After the surgery, the patient responded well. The plasma ACTH levels decreased to $25 \mathrm{pmol} / \mathrm{L}$. Cortisol level decreased to $6 \mu \mathrm{g} / \mathrm{dL}$. Blood pressure decreased to $130 / 80$. Overall, the patient was symptomatically well with good lung function.

\section{Discussion}

Carcinoid was first discovered in late 19th century by Lubarsh, who found multiple tumors in the small bowel of two patients at autopsy. In neuroendocrine tumors, 3 grades on histologic features and biologic behavior are currently recognized-

- Grade I or typical carcinoid

- Grade II or atypical carcinoid

- Grade III or small cell carcinoma/large cell carcinoma

Typical carcinoids occur in both sexes and age of onset ranges from childhood to 9th decade. Atypical carcinoid appear in older age groups. Typical carcinoids are well differentiated, can exhibit distinct recognized histologic pattern (insular, trabecular, glandular, mixed or undifferentiated) and rare mitoses. They usually present as perihilar masses and are generally asymptomatic; however some patients may present recurrent pneumonia, cough, hemoptysis and chest pain. Ectopic secretion of biologically active hormones is not uncommon, in particular corticotrophin and growth hormone and it occurs in fewer of $5 \%$ of patients with these tumors. Conversely, atypical carcinoids represent an intermediate grade neuroendocrine tumors; they may exhibit increased nuclear atypia, focal necrosis or high mitotic indices and their clinical course is aggressive with an high incidence of mediastinal lymph node metastases and a 5-year survival rate of $40-75 \%$ [7].

The differential diagnosis of Cushing syndrome and in differentiation of pituitary Cushing syndrome from 
An ectopic ACTH secreting neoplasm can be difficult [8]. The most useful test is inferior petrosal sinus sampling where patients with pituitary lesions show a gradient in ACTH concentration between the affected side sinus and the periphery in contrast to an ectopic ACTH syndrome where there is no gradient [9]. Localization of the source of ectopic ACTH can be problematic [10]. Small peripheral bronchial carcinoids can be easily missed on CT chest due to poor inspiratory effort, abdominal fat [11].

Confirmation of ectopic ACTH production requires demonstration of immunostaining positive for $\mathrm{ACTH}$ in the resected tumour. This may be difficult if the source was metastatic malignancy as in this case only a subpopulation of the cells will produce ACTH making it difficult to be demonstrated by staining. More recently, extraction of appropriate mRNA by real time PCR provides a highly specific means of identifying these tumours [12].

Advances in medical and surgical treatments have improved the overall survival rate for patients with ectopic ACTH [13]. Prognosis depends on primary tumor histology [14]. Patients with small cell lung carcinoma (SCLC) had the worst prognosis, usually dying within 12 months of diagnosis (median 6-8 months) $[15,16,17]$. Patients with bronchial carcinoids have the best prognosis and are usually considered to have low to moderate grade malignancy [18]. They do have a malignant potential, however, and can be associated with metastases.

\section{Conclusion}

Ectopic ACTH secreting tumors present some of the most challenging differential diagnosis in endocrinology and require careful clinical, radiological and pathological investigation. These tumors are best managed in a managed in a multidisciplinary setting with close relation between the endocrinologist, endocrine surgeon, pathologist and radiologist.

\section{Reference}

01. Ye L, Li X, Kong X, Wang W, Bi Y, Hu L, et al. Hypomethylation in the promoter region of POMC gene correlates with ectopic overexpression in thymic carcinoids. J Endocrinol. 2005;185(2)337-343.

doi: [Article:https://doi.org/10.1677/joe.1.05963] [Crossref]
02. Boddaert G, Grand B, Le Pimpec-Barthes F, Cazes A, Bertagna $X$, Riquet $M$. Bronchial carcinoid tumors causing Cushing's syndromemore aggressive behavior and the need for early diagnosis. Ann Thorac Surg. 2012;94(6)18231829.

doi: https://doi.org/10.1016/j.athoracsur. 2012.07.022[Crossref]

03. Deb SJ, Nichols FC, Allen MS, Deschamps C, Cassivi SD, Pairolero PC. Pulmonary carcinoid tumors with Cushing's syndrome- an aggressive variant or not?. Ann Thorac Surg. 2005;79(4)1132-1136.

doi:

[Article:https://doi.org/10.1016/j.athoracsur.2004.07 .021][Crossref]

04. Riggs BL, Sprague RG. Association of Cushing's syndrome and neoplastic disease- Observations in 232 cases of Cushing's syndrome and review of literature. Arch Int Med. 1961;108(6)841849.

doi:

[Article:https://doi.org/10.1001/archinte.1961.03620 120025005][Crossref]

05. DG Gardner and D Shoback. Greenspan's Basic \& Clinical Endocrinology. Lange, 9th edition. 2007.

[Crossref]

06. Pedicelli I, Patriciello G, Scala G, Sorrentino A, Gravino $G$, Patriciello $P$, et al. Cushing's like syndrome in typical bronchial carcinoid a case report and review of the literature. Int J Surg Case Rep. 2016;20S;1-4. doi:[Article:https://doi.org/10.1016/j.ijscr. 2016.02.006][Crossref]

07. Nenekidis I, Stathopoulos GT, Anagnostakou V, Kokkori A, Dedeilias P, Kokotsakis J, et al. Atypical pulmonary carcinoid tumour in a 28year-old nonsmoker with Prader-Willi syndrome. Europe Resp J. 2011;38(5)1230-1233. doi:

[Article:https://doi.org/10.1183/09031936.00034711 ][Crossref]

08. Ilias I, Torpy DJ, Pacak K, Mullen N, Wesley RA, Nieman LK. Cushing's syndrome due to ectopic corticotropin secretion- twenty years' experience at the National Institutes of Health. J Clinic Endocrinol Metabol. 2005;90(8)49554962.

doi: [Article:https://doi.org/10.1210/jc.2004-2527] [Crossref] 
09. Kaltsas GA, Giannulis MG, Newell-Price JD, Dacie JE, Thakkar C, Afshar F, et al. A critical analysis of the value of simultaneous inferior petrosal sinus sampling in Cushing's disease and the occult ectopic adrenocorticotropin syndrome. J Clinic Endocrinol Metabol. $1999 ; 84(2) 487-492$.

doi:

[Article:https://doi.org/10.1210/jcem.84.2.5437]

[Crossref]

10. S Melmed, KS Polonsky, R Larsen, and HM Kronenberg. Williams Textbook of Endocrinology. Saunders Elsevier. 12th edition, 2011.

[Crossref]

11. Doppman JL, Nieman L, Miller DL, Pass HI, Chang $\mathrm{R}$, Cutler Jr GB, et al. Ectopic adrenocorticotropic hormone syndromelocalization studies in 28 patients. Radiol. 1989;172(1)115-124.

doi: [Article:https://doi.org/10.1677/joe.1.05963] [Crossref]

12. Beuschlein F, Hammer GD. Ectopic proopiomelanocortin syndrome. Endocrinol Metabol Clinic North Am. 2002;31(1)191-234.

doi: [Article:https://doi.org/10.1016/s08898529(01)00025-1][Crossref]

13. Venugopal $H$, Griffin $K$, Amer S. A case of severe ectopic ACTH syndrome from an occult primarydiagnostic and management dilemmas. Endocrinol, Diab Metabol Case Rep. 2015(1).

doi: [Article:https://doi.org/10.1530/EDM-15-0099] [Crossref]
14. Isidori AM, Kaltsas GA, Pozza C, Frajese V, Newell-Price J, Reznek $\mathrm{RH}$, et al. The ectopic adrenocorticotropin syndrome- clinical features, diagnosis, management, and long-term followup. J Clinic Endocrinol Metabol. 2006;91(2)371377.

doi: [Article:https://doi.org/10.1210/jc.2005-1542] [Crossref]

15. Kenchaiah M, Hyer S. Cushing's syndrome due to ectopic acth from bronchial carcinoid- A case report and review. Case reports in endocrinology. 2012; 215038.

doi:

[Article:https://dx.doi.org/10.1155\%2F2012\%2F215 038][Crossref]

16. Nunes JM, Pinho E, Camões I, Maciel J, Bastos PC, de Moura CS, Bettencourt P. A challenging case of an ectopic Cushing syndrome. Case reports in medicine. 2014.

doi: [Article:https://doi.org/10.1155/2014/413136] [Crossref]

17. Salameh JR, Borman KR, Varkarakis GM. Laparoscopic bilateral adrenalectomy for occult ectopic ACTH syndrome. J Laparoendoscop Advanc Surg Tech. 2008;18(1)52-55.

doi: [Article:https://doi.org/10.1089/lap.2007.0016][ Crossref]

18. Salgado LR, Fragoso MC, Knoepfelmacher $M$, Machado MC, Domenice S, Pereira MA, de Mendonça BB. Ectopic ACTH syndrome- our experience with 25 cases. European Journal of Endocrinology. 2006 Nov 1;155(5)725-733.

doi: [Article:https://doi.org/10.1530/eje.1.02278] [Crossref] 